\title{
Are there options outside livestock economy? Diversification among households of northern Kenya
}

\author{
Patrick Wekondi Watete ${ }^{1,2^{*}}$, Wambui-Kogi Makau ${ }^{3}$, Jesse Theuri Njoka ${ }^{3}$, Laban AderoMacOpiyo ${ }^{1}$ \\ and Stephen Mwangi Mureithi ${ }^{3}$
}

\begin{abstract}
Income diversification has been hailed by some policy-makers as an important ingredient for building pastoral resilience. This study applied the sustainable livelihood approach to establish the determinants of diversification among pastoral households of Turkana and Mandera Counties. In these Counties, 300 and 362 households, respectively, were identified through multi-stage sampling. A participatory wealth-ranking method was used to categorize the sampled households into three poverty levels: poor, middle and rich. The number of income sources, distance to water source, education level of household head, Tropical livestock units (TLUs) held, durable index (a measure of physical asset ownership) and age of the household head influenced the choice of livelihood strategy, whether pastoral, agro-pastoral or off-farm. Although diversification among pastoral communities is on the increase, it is important to promote activities that complement pastoralism among communities of northern Kenya. Improved education levels and better access to water are important factors in encouraging adoption of non-livestock-based income-generating activities.
\end{abstract}

Keywords: Diversification, Pastoral, Northern Kenya, Livelihood strategies, Off-farm

\section{Background}

Livelihood diversification is the process by which households combine diverse portfolios of activities and assets in order to improve their welfare (Ellis 2000; Scoones 1998). Little et al. (2006) have defined livelihood diversification among pastoralists as 'the pursuit of any nonpastoral income earning activity, whether in rural or urban areas'. Several reasons have been advanced to suggest why diversification takes place. According to Ellis (2000) and Barrett et al. (2001), the two reasons for diversification are necessity and choice. Poor households succumb to push factors that make them diversify out of necessity so as to survive, while wealthier households take advantage of the pull factors that present them with opportunities of creating wealth. Von Broun and Pandya-Lorch (1991) see diversification as ex ante risk

\footnotetext{
* Correspondence: pwatete@gmail.com

${ }^{1}$ Land Resource Management and Agricultural Technology Department, University of Nairobi, Nairobi, Kenya

${ }^{2}$ Animal Health and Industry Training Institute (AHITI), Kabete, Kenya

Full list of author information is available at the end of the article
}

minimization and ex post coping strategy. Diversification can have both positive and negative outcomes, depending on factors that make a household to diversify.

Several forces are pushing pastoral households of northern Kenya to diversify. The current resource base is inadequate to support livestock numbers needed to sustain a purely pastoral system (Kandagor 2005; Sandford 2006), and so the need to avail alternative livelihood options to individuals who drop out of the pastoral production system is necessary and urgent. Diversification is also increasing with sedentarization, both forced from loss of access to grazing lands and drought-related destitution and proactive sedentarization of individuals who wish to grasp new economic opportunities (Fratkin 2012; Catley and Scoones 2013).

This study has applied the sustainable livelihood approach (SLA) framework to analyse pastoral livelihoods. The SLA framework (Figure 1) has classified household assets into five categories, namely human capital,
焦 Springer

(c) 2016 Watete et al. Open Access This article is distributed under the terms of the Creative Commons Attribution 4.0 International License (http://creativecommons.org/licenses/by/4.0/), which permits unrestricted use, distribution, and reproduction in any medium, provided you give appropriate credit to the original author(s) and the source, provide a link to the Creative Commons license, and indicate if changes were made. 


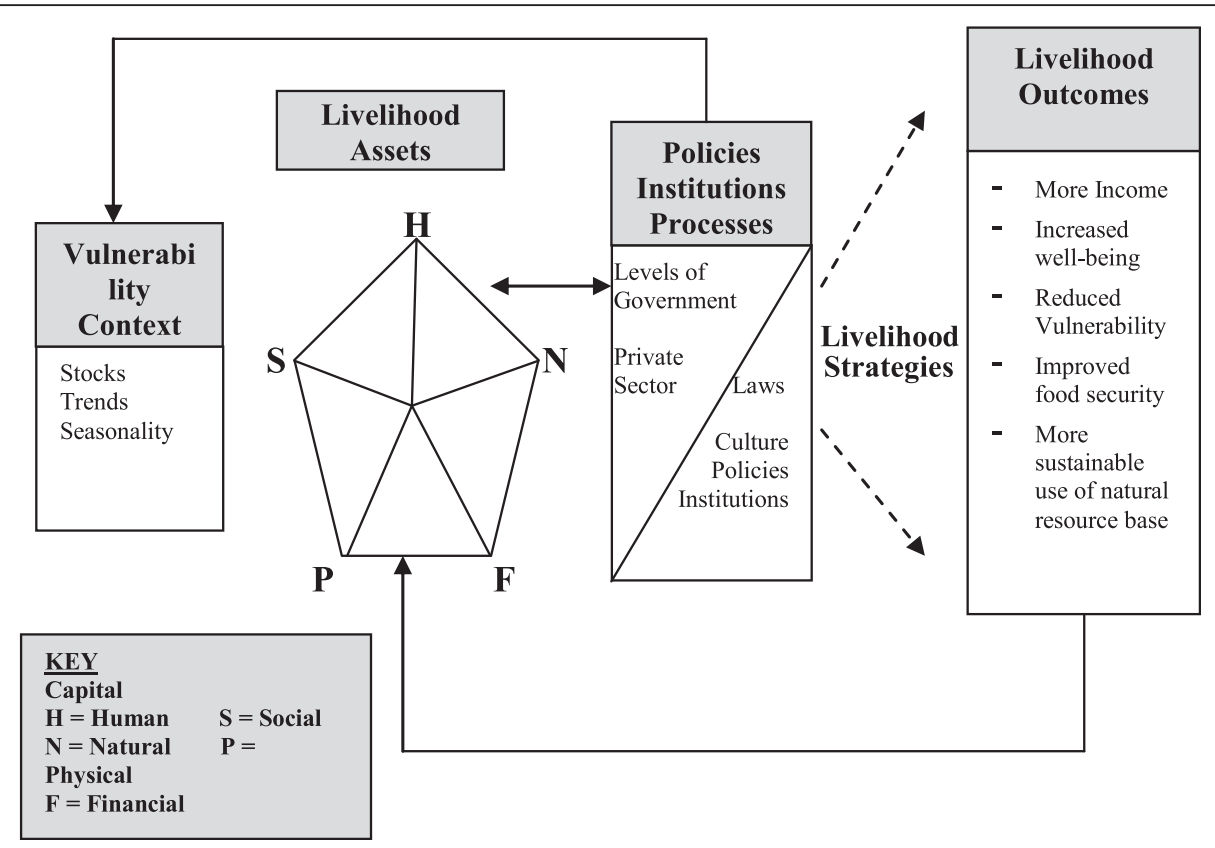

Figure 1 The theoretical model depicting the relationship between household assets, livelihood strategies and livelihood outcomes. Source: Carney (1999)

financial capital, physical capital, natural capital and social capital.

Human capital represents the skills, knowledge, ability to labour and good health that together enable people to pursue different livelihood strategies and achieve their livelihood objectives (Ellis 2000). Human capital is therefore constituted by both the quantity and quality of labour available. Human capital is required to make use of the other four types of assets. At household level, human capital is usually determined by household size, education, skills and health of the household members.

Financial capital denotes the financial resources that people use to achieve their livelihood objectives. It includes the availability of cash or equivalent that enables people to adopt different livelihood strategies. In a pastoral community, an important component of financial capital is livestock, which acts as a store of wealth and buffer against bad times (Ellis 2000). Financial capital is made up of available stocks (anything that can be liquidated to meet cash requirements) and regular inflows of cash (income from farm produce sales, wages and remittances from household members working away from the homestead).

Physical capital is that capital that is created by economic production. It includes infrastructure such as roads, irrigation works, electricity, reticulated equipment and housing. For physical capital, ownership is only a measurement of access, as the high degree of reciprocity allows non-owners to access some of the key physical assets.
Natural capital consists of land and other resources such as trees, pastures, water and biodiversity. The productivity of these resources may be degraded or improved by human management (Elasha et al. 2005). Natural capital therefore involves natural resource stocks from which resource flows and services useful for livelihoods are derived. Pastoral households are dependent on these environmental resources for firewood, water, waste disposal, grazing land and crop production activities.

In the context of sustainable livelihood framework, social capital is taken to mean the social resources upon which people draw in pursuit of their livelihood objectives. Social capital refers to features of social organization such as networks, norms and social trust that facilitate coordination for mutual cooperation. Social capital can be used to reduce poverty by affecting information flow among the poor, thus improving economic growth and income redistribution (Grootaert and Bastelaer 2002).

Studies have found a positive correlation between households' welfare and their involvement in other nonfarm activities (Stifel 2010; Reardon et al. 2001; Barrett et al. 2001). These studies have also found that rural households with the ability to diversify their income sources to other non-farm activities tend to perform better economically than those that depend wholly on farm activities or those that take up non-farm activities as a coping strategy. It has also been observed that poor households are prevented from taking up superior livelihood strategies due to a number of entry barriers. These barriers include low asset endowment, access to formal 
credit, information or markets, and demographic factors such as level of education, sex or age of the household head (Stifel 2010; Brown et al. 2006; Barrett et al. 2001). These barriers will constrain a household from taking up more lucrative livelihood strategies. Diversification is therefore a coping strategy that households use to maintain their level of welfare and ensure achievement of food security.

Some policy-makers see diversification as a necessary strategy that may be useful in enhancing resilience among pastoral households (Republic of Kenya 2012: 22-23). However, there is little understanding about the diversification process, its drivers and how it impacts on pastoral welfare.
This study looks at pastoral livelihoods and assets in a case study and how these determine the ability of a household to diversify. It looks at livelihood outcomes associated with various livelihood options as a basis of recommending asset and livelihood combinations that may enhance pastoral resilience.

\section{Study area}

The study was carried out in Turkana and Mandera Counties, Kenya (Figure 2).

Mandera County (Figure 3) is situated in the northeastern part of Kenya and covers an area of $26,474 \mathrm{~km}^{2}$. It borders Ethiopia to the north and Somalia to the east. On the western side, it borders Wajir County. The

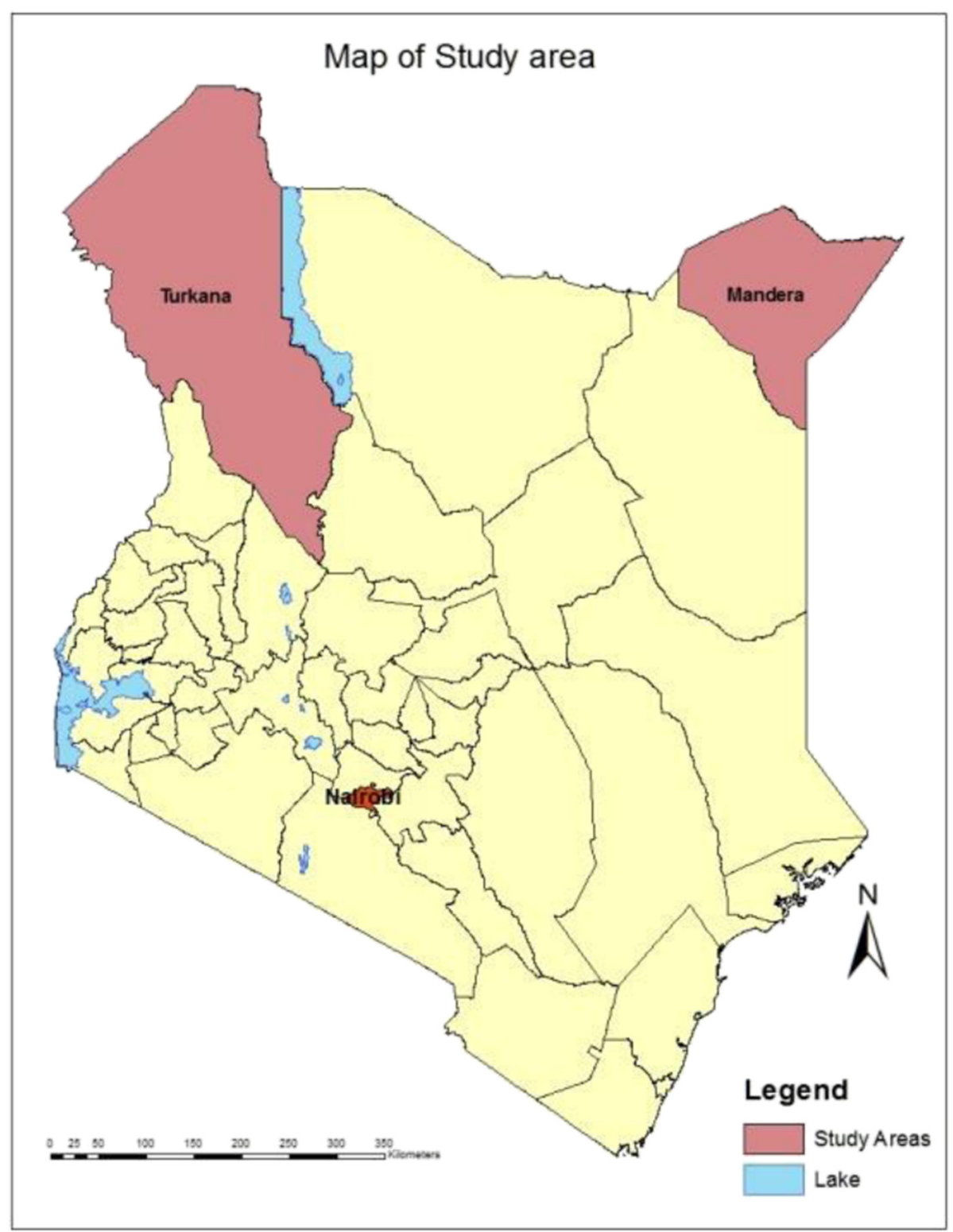

Figure 2 Map of the study area 


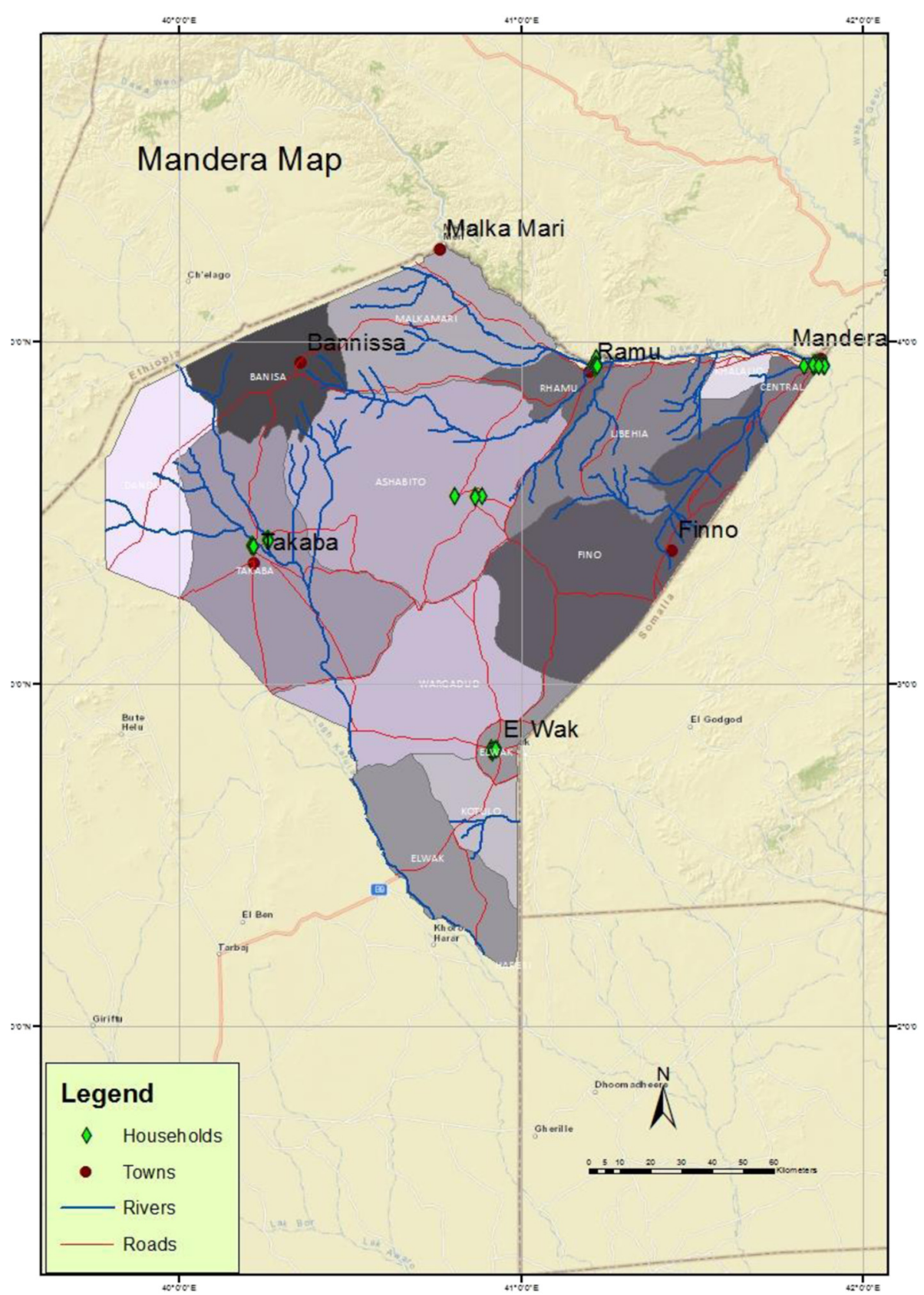

Figure 3 Mandera County

County has three main livelihood zones: a pastoral economy zone on the eastern side, an agro-pastoral economy zone on the western side and an irrigation zone on the northern end along the Daua river. Pastoralism is the main economic activity and is practiced by $60 \%$ of the population. Over $95 \%$ of households access some food through the market. Horticultural crops, especially watermelons and bananas, are produced under irrigation. Some maize is grown but is usually sold as fodder. The recurring droughts have made most households' food insecure as they lack the means to purchase food once they lose most of their livestock.

Turkana County (Figure 4) is the second largest County in Kenya, with a land area of $68,680 \mathrm{~km}^{2}$. It borders Uganda to the west, Sudan and Ethiopia to the north, Samburu and Marsabit Counties to the east and to the south it borders Baringo and West Pokot Counties. It lies between latitudes $0^{\circ} 51^{\prime}$ and $5^{\circ} 30^{\prime} \mathrm{N}$ and longitudes $34^{\circ}$ and $30^{\circ} 40^{\prime} \mathrm{E}$. The headquarters of the County are at Lodwar town. The County plays host to hundreds of refugees who have been displaced from 


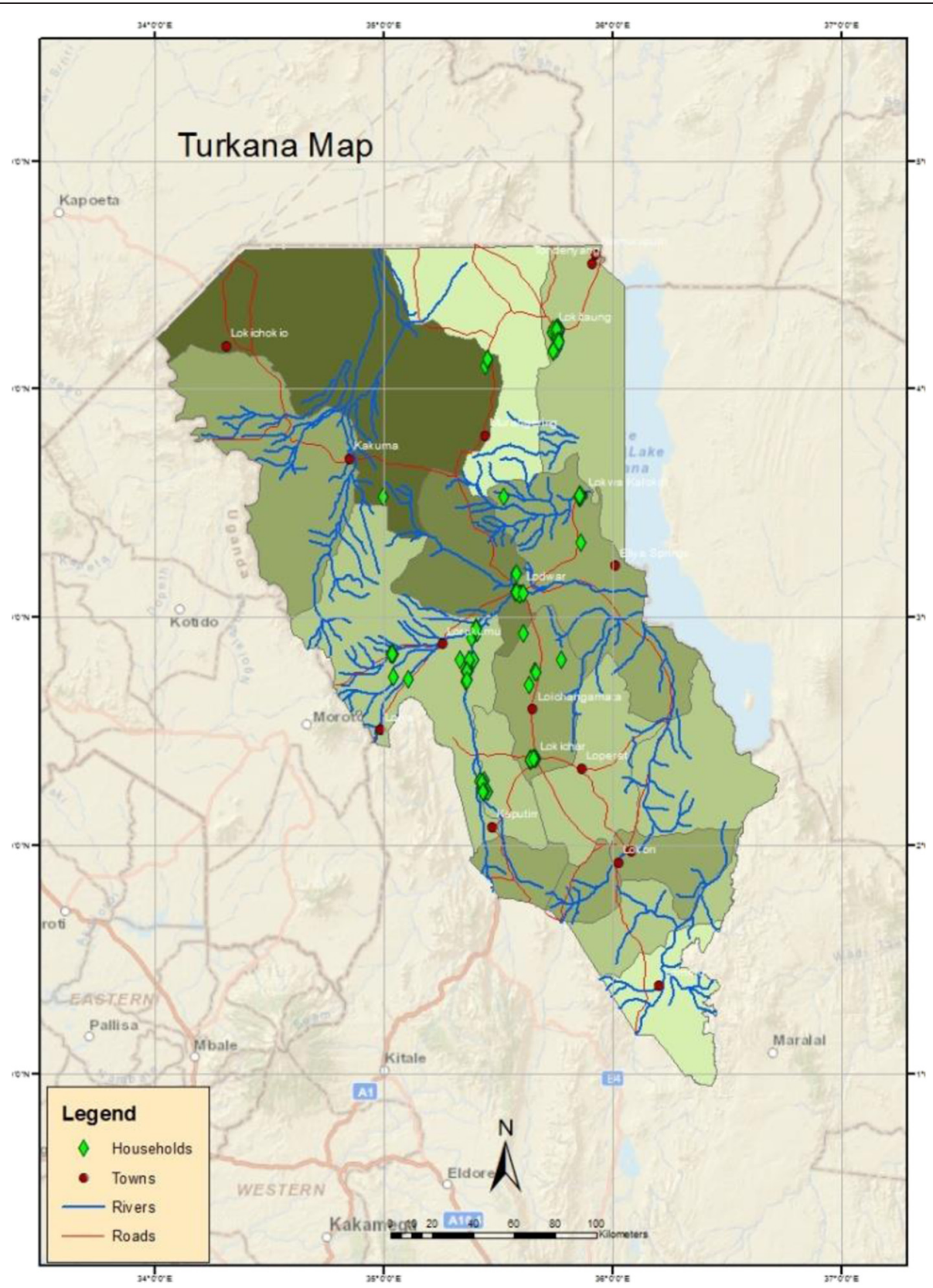

Figure 4 Turkana County

their countries of origin at Kakuma refugee camp located $120 \mathrm{~km}$ from Lodwar town. It was established in 1992 to host Sudanese refugees, but other refugees from Somalia, Eritrea, Burundi, Uganda, Democratic Republic of Congo, Ethiopia and Rwanda have added to the swelling refugee population. Kakuma refugee camp had a population of 605,364 refugees as of December 2014 (UNHCR 2000). This study however did not include any respondents from the refugee camp. The main socioeconomic activity in the County is nomadic pastoralism. Due to the arid nature of the County, livestock mobility is practiced to ensure access to water and pasture resources. Insecurity sometimes constrains mobility and herders are forced to settle in less habitable areas, making them more vulnerable to drought. The main livestock species kept are indigenous cattle, sheep, goats, camels and donkeys. Bee keeping and indigenous poultry rearing are also practiced by a few households. Crop farming is also a major livelihood that has been taken up by settled communities. Most of the crop farmers are former pastoralists who have dropped out of pastoralism after they lost viable livestock herds. Crop farming is 
either rain-fed or irrigated. The major irrigation belt lies along the Turkwel and Kerio rivers. The main crops grown under these schemes are maize, sorghum, beans, cowpeas, bananas, mangoes and guavas. Agro-pastoralists comprise about $20 \%$ of the County population. Fishing is practiced in Lake Turkana, the biggest inland lake in Kenya with an area of 7,560 $\mathrm{km}^{2}$. The lake is $265 \mathrm{~km}$ long and $40 \mathrm{~km}$ wide. Fishing in Lake Turkana is done at subsistence level. Commercial fishing is constrained by poor infrastructure that limits market access, fluctuating water levels that make fish harvests equally fluctuating and a poor fish-eating culture among the Turkana. About $12 \%$ of the County population derives its livelihood from fishing. The remaining $8 \%$ of the County population is engaged in either formal or informal employment or petty business.

\section{Methods}

\section{Sampling procedure and data collection}

A multi-stage approach was used to sample 330 and 390 households in Mandera and Turkana Counties, respectively. In the first stage, Sub-Counties in the two Counties were purposively identified based on predominant livelihood strategies pursued, whether pastoral, agropastoral or off-farm. For each livelihood zone, at least three villages per County were identified through a balloting process. The overall number of villages identified for the study was therefore 11 and 13 for Mandera and Turkana, respectively. In each village, 30 households were systematically sampled from lists obtained from the local chiefs. Table 1 shows how sample households were identified in the two Counties.

The first stage of the study involved administration of questionnaires to the 720 households. The questionnaire captured household socio-economic characteristics of the household, sources of household income and income earned by each source.

The second stage of the study involved focus group discussions (FGDs) carried in 11 villages and 13 villages in Mandera and Turkana Counties, respectively, where the sample households had been identified. A participatory wealth-ranking approach was used to categorize sample households into various wealth categories. FGDs involved the use of 'the stages of progress' method to determine how poverty level varied across households and over the years.

\section{Focus group discussions}

These were done during the second stage of data collection. We carried out FGDs in 11 villages in Mandera and 13 villages in Turkana Counties one month after the completion of household interviews. These FGDs were done in all the villages from which household interview respondents had been identified. FGDs were used to establish household poverty dynamics over the last two decades using 'the stages of progress' method and also to determine the reasons associated with ascent from poverty or descent into poverty (Krishna 2010).

'The stages of progress' is a participatory method that relies on community focus group meetings to delineate locally applicable 'stages of progress' that poor households are assumed to follow as they make their way out of poverty (Krishna 2010). This is a rapid method that captures data that would otherwise require a longer time and more resources. These stages were then used to create 'yardsticks' by which households' welfare was measured at different points in time.

During the FGDs, the local chiefs assisted in identifying between 8 and 10 individuals who had been residents of the village for at least the previous 20 years and who knew well the household heads from the sampled households. The focus group comprised a mixture of resourceful men and women and one literate young man who assisted in translating and recording the discussion. To ensure that the participating community members gave useful information, the objectives of the exercise were stated and it was emphasized that their participation was voluntary with

Table 1 Sample locations and sizes

\begin{tabular}{|c|c|c|c|c|c|}
\hline \multicolumn{3}{|l|}{ Mandera } & \multicolumn{3}{|l|}{ Turkana } \\
\hline Location & Number of households & Livelihood & Location & Number of households & Livelihood \\
\hline Mandera Township & 120 & Agro-pastoral and off-farm & Namurputh & 30 & Pastoral \\
\hline Rhamu & 60 & Agro-pastoral & Turkwel & 90 & Agro-pastoral \\
\hline Takaba & 60 & Pastoral & Nakwamekwi & 30 & Off-farm \\
\hline Elwak & 60 & Pastoral & Katilu & 60 & Agro-pastoral \\
\hline \multirow[t]{3}{*}{ Ashibito } & 30 & Pastoral & Lokichar & 30 & Off-farm \\
\hline & & & Kalokol & 30 & Off-farm \\
\hline & & & Lokitaung & 120 & Pastoral \\
\hline Total & 330 & & & 390 & \\
\hline
\end{tabular}


no material advantages. Participants were guided to define collectively what it meant for a household to be poor. The participants were then guided to develop a 'stages of progress' ladder that was used as a scale of categorizing households into wealth strata, whether poor, middle or rich.

Participants were asked to identify well-known signifying events that had occurred 10 years and 20 years earlier (2003 and 1993). In 1993, the Turkana and Mandera community members remembered a famine (referred to as the Red Cross famine) and the ouster of President Siad Barre of Somalia, respectively. Participants in both Counties associated 2003 with the NARC (National Rainbow Coalition Political Party) victory when Mwai Kibaki was elected President of Kenya for the first time. These were then used as reference points during the categorization of households.

\section{Data analysis}

Data was coded, entered into a computer, cleaned and analysed using SPSS (version 20), through descriptive and inferential statistics. All hypotheses were tested at $\alpha=$ 0.05. The Kruskal-Wallis test was used to evaluate whether population medians on a variable were equal across all levels of a factor. This test is useful when the data are measurements in an ordinal scale. Whenever the Kruskal-Wallis test indicated a significant difference between groups, the Mann-Whitney test was used to make pair-wise comparisons to identify those groups that were significantly different.

ANOVA was used to compare interval and ratio variables across households by livelihood strategies and County.

Even though households were sampled along predominant livelihood zones, the final categorization of a household as either pastoral, agro-pastoral or off-farm was based on the contribution of livestock or crop income to total household income.

Pastoral household was that household in which $50 \%$ or more of household gross revenue (i.e. the total value of marketed production plus the estimate value of subsistence production consumed within the household) came from livestock or livestock-related activities (Bonfiglioli \& Watson (1992)).

Agro-pastoral household was one in which more than $50 \%$ of household gross revenue came from farming of crops and the remaining $10 \%$ to $50 \%$ from livestock or livestock-related activities (Bonfiglioli \& Watson 1992)

Off-farm household was a household where there were other alternative sources of income different from livestock or crop income such that the overall contribution made by either livestock or crop production was less than $50 \%$.

\section{Results}

Main sources of household income across livelihood strategies

All households received income from a variety of sources. At least $30 \%$ of off-farm households received income from eight possible sources: livestock sales, milk sales, sale of other livestock products, salary, wages, charcoal/firewood, crops and business. For pastoral households, at least $30 \%$ of them received income from five sources: livestock sales, milk sales, sale of other livestock products, charcoal/firewood and crops (Figure 5).

\section{Proportion of income contributed by various sources across livelihood strategies}

Off-farm households earned the bulk of their income (including imputed value of subsistence income) from salaries, livestock products, firewood/charcoal and crops, totaling to an average of KShs 76,000 per year (USD 778). At the same time, pastoral households earned the bulk of their income from sale of livestock and livestock products, firewood/charcoal and crops, earning an average of KShs 70,000 (USD 833) per year. Agro-pastoral households received the least income of KShs 15,000 (USD 167) per year, mainly from crops and livestock products (Figure 6).

\section{Gender and income sources}

Both male- and female-headed households participated in all income-generating activities but at different levels (Figure 7). There was a significant difference in the sex of household heads who were engaged in milk trade $(p=0.22)$, who received salary income $(p<0.001)$, income from firewood $(p=0.041)$, crop income $(p<$ $0.001)$ and business income $(p=0.003)$.

Diversification was also influenced by gender of the household head (Table 2). Male-headed households tended to diversify more than female-headed households.

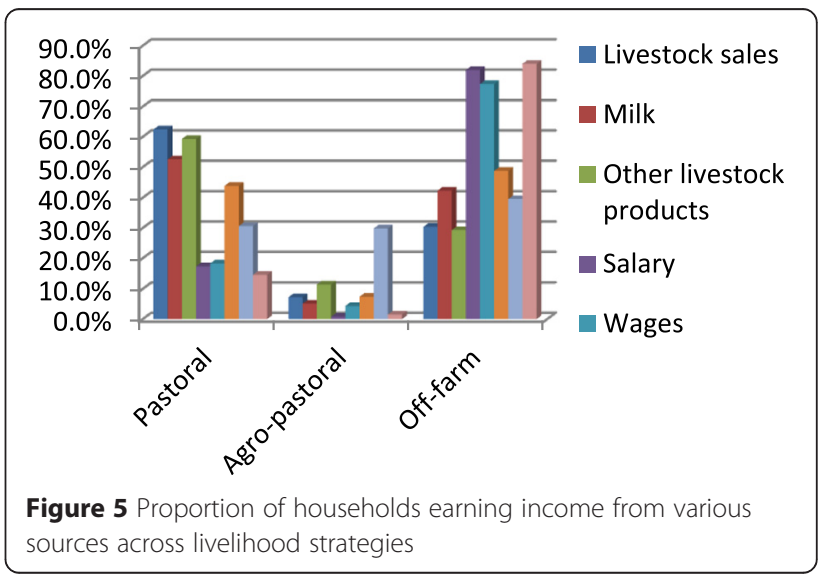




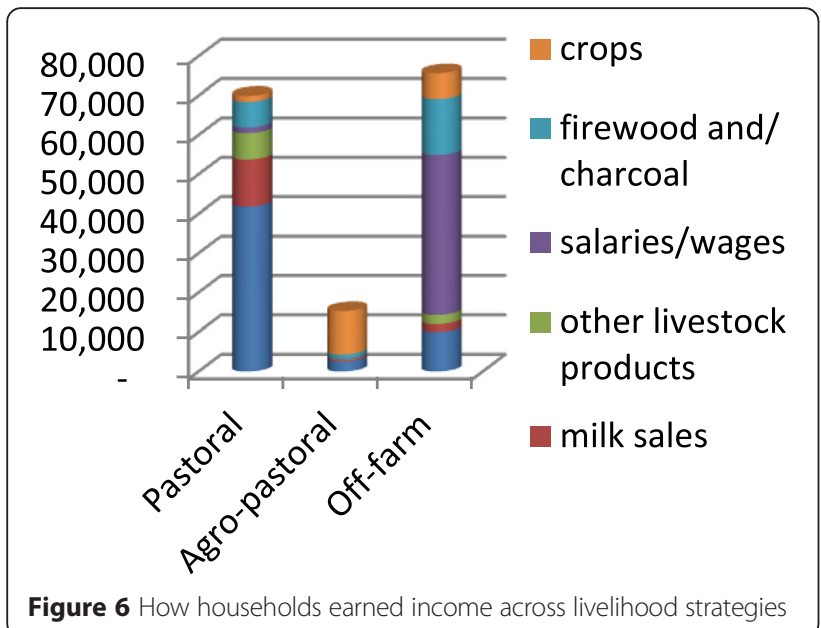

\section{Sources of income by County}

Households in Turkana and Mandera received $61 \%$ and $77 \%$, respectively, of their total income from nonlivestock sources (Table 3).

\section{Sources of income and household welfare status}

The major sources of income for most households across all the wealth categories were livestock sales, firewood/charcoal and sale of other livestock products (apart from milk). For wealthier households, receipt of wages was also a major source of income (Figure 8).

\section{Assets and livelihood strategies}

Various assets and socio-economic indicators were compared across the three livelihood strategies (Table 4).

Heads of households pursuing off-farm strategies were relatively younger compared to their counterparts pursuing pastoralism and agro-pastoralism. They also had more years of formal education. Pastoral households owned more livestock and had to walk for longer distances to obtain water.

Agro-pastoral households on the other hand had higher scores for durable index (an indicator of

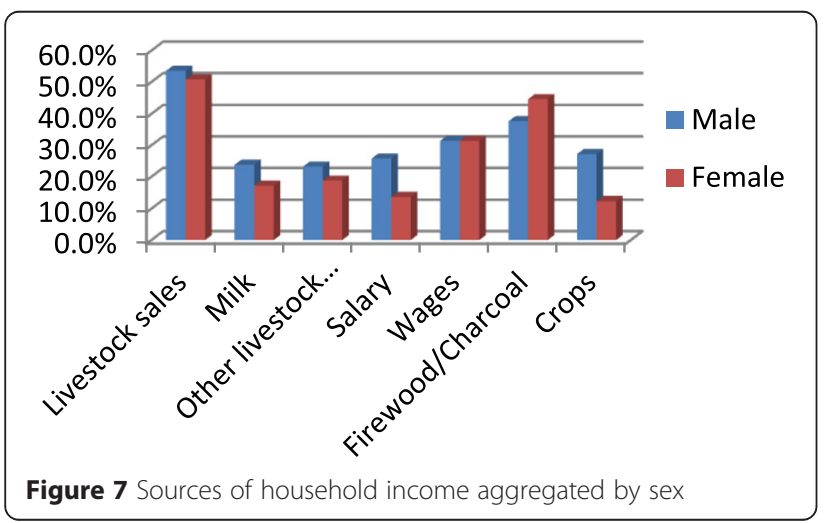

Table 2 Mean of diversification index by sex

\begin{tabular}{llll}
\hline & Mean & SD & pvalue \\
\hline Female $(N=304)$ & 1.26 & .735 & \\
Male $(N=358)$ & 1.57 & 1.091 & $<0.001$ \\
\hline
\end{tabular}

ownership of assets) compared to both pastoral and offfarm households.

Apart from age of the household head, all the other household socio-economic factors showed very significant differences (at $\alpha=0.05$ ) across the livelihood strategies.

A number of household characteristics influenced the ability of a household to pursue a given livelihood strategy. Factors that influenced a household to pursue pastoral and off-farm livelihoods were the number of income sources, distance to the water source, number of years of schooling of the household head, age of the household head, number of livestock held (TLU) and durable index. The number of income sources and education level were associated with whether a household pursued agro-pastoral or off-farm strategies.

\section{Discussion}

Pastoral and off-farm households exhibited more diversification (evidenced by the number of income generation activities) compared to agro-pastoral households, and these differences were significant $(p<0.001)$ in the proportion of households that were engaged in livestock sales, milk sales, salary, business, wages, charcoal/firewood and crops. Households that had been categorized as off-farm participated in a wider variety of income activities. At least $30 \%$ of these households were involved in seven different income activities, earning an average of KShs 75,000 (USD 833) per year. They were followed by pastoral households where at least $30 \%$ of such households earned income from five different sources,

Table 3 Proportion (percent) of income contributed by each source

\begin{tabular}{lll}
\hline Income source & County & Mandera \\
\cline { 2 - 3 } & Turkana & $(N=365) \%$ \\
\hline Livestock & 39 & 23 \\
Crops & 8 & 4 \\
Salaries/wages & 15 & 28 \\
Business & 10 & 15 \\
Charcoal/firewood & 18 & 11 \\
Remittances & 1 & 6 \\
Other sources & 8 & 13 \\
\hline
\end{tabular}




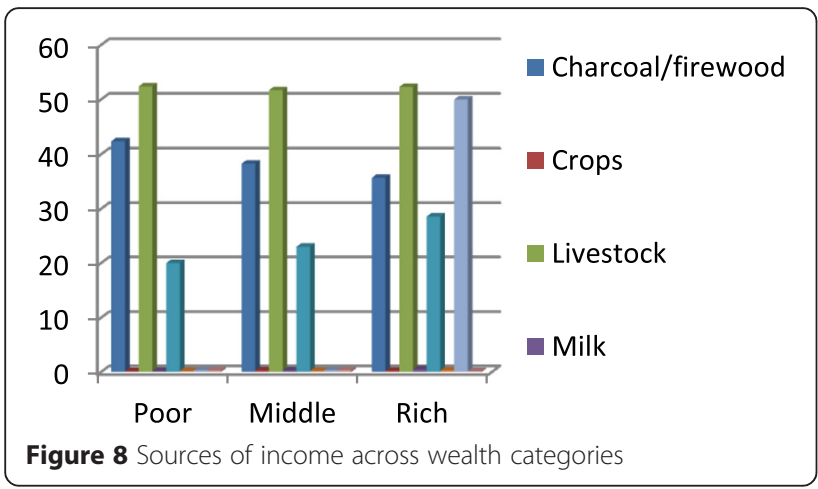

total income averaging KShs 70,000 (USD 778) per year. Agro-pastoral households received the least income with the greatest portion of their income coming from crops and relatively little income derived from livestock and sale of charcoal. Agro-pastoral households had an average income of KShs 15,000 (USD 167) per year. For agropastoral households, the value of home-consumed produce was not exhaustively established, leading to undervaluation of gross household income. Agro-pastoral households tended to diversify the least compared to pastoral and off-farm households. Crop farming demanded more labour compared to the other enterprises, and so individuals undertaking crop production were unable to take up more income-generating activities due to labour constraints. This observation agrees with other studies (Stifel 2010; Reardon et al. 2001; Barrett et al. 2001) that have established a positive correlation between households' welfare and their involvement in other non-farm activities.

For off-farm households, the greatest portion of income was derived from salaries/wages. Households that received salaries were adequately cushioned against livelihood shocks and were able to remain well-off. The other livelihood activities such as charcoal/firewood sales and to some extend crop production seemed to be coping strategies as they contributed very little income to the household.

Female-headed households were associated with a lower diversification index than male-headed households (Table 5), indicating that female-headed households had fewer streams of income compared to men. This could be explained by the observation that women have to combine new roles with their normal household chores. This may limit their ability to take up extra income generation opportunities. Gender affects diversification options as gender roles are culturally determined, mobility of females may be constrained and females experience differential access to assets (Dhanaraj 2015).

Most households, irrespective of their welfare status, depended on three major sources of income: sale of livestock (live animals), sale of livestock products and sale of charcoal/firewood. Rich households had a fourth source of income: wages that supported $50 \%$ of these households. Dependence on charcoal/firewood as a source of income declined with improved welfare status, an indication that this activity was more of a coping strategy than an income generation activity.

Off-farm strategies seemed to attract younger and relatively well-educated individuals. This is understandable as pursuance of either pastoral or agro-pastoral livelihoods required accumulation of a viable livestock herd and access to assets for farming. The need to accumulate such assets acted as barriers that prevented younger persons from pursuing pastoral and agro-pastoral activities.Off-farm opportunities pursued by Turkana and Mandera pastoralists seemed to be less remunerative compared to pastoralism and agro-pastoralism, an indication that households undertook off-farm activities as a coping strategy. This observation agrees with other studies that have observed that poor households are prevented from engaging in more remunerative activities due to barriers such as age, education and sex (Stifel 2010; Brown et al. 2006).

Table 4 Means of various socio-economic factors across livelihood strategies

\begin{tabular}{|c|c|c|c|c|}
\hline \multirow[b]{2}{*}{ Household characteristics } & \multicolumn{3}{|c|}{ Livelihood strategy } & \multirow[b]{2}{*}{$p$ value } \\
\hline & Pastoral & Agro-pastoral & Off-farm & \\
\hline Age of household head & 47.67 & 48.10 & 44.21 & 0.019 \\
\hline Years of formal schooling of the household head ${ }^{a}$ & .98 & 2.32 & 2.81 & $<0.001$ \\
\hline Tropical livestock units ${ }^{\mathrm{ab}}$ & 9.06 & 2.06 & 3.46 & $<0.001$ \\
\hline Durable index ${ }^{a}$ & 1.62 & 2.40 & 2.13 & $<0.001$ \\
\hline Diversity of income sources ${ }^{a}$ & 1.12 & 1.83 & 1.56 & $<0.001$ \\
\hline Hours taken to walk to water source ${ }^{a}$ & 2.73 & 1.11 & 1.61 & $<0.001$ \\
\hline
\end{tabular}

${ }^{a}$ Significant at $99 \%$ significant level. Durable index is a measure of asset endowment of a household. The assets considered were plough, bicycle, radio, TV and pack animals. For each of the assets owned by a household, a score of one was given and zero if the asset was absent. The durable index of a household was given by the summation of the asset scores

${ }^{b}$ Tropical livestock units (TLUs). One TLU was taken as equivalent to an animal weighing $250 \mathrm{~kg}$. The conversion factors used were $0.7,0.1,0.1$ and 1.0 for cattle, goat, sheep and camel, respectively (Tache and Sjaastad 2010). 
Table 5 Logistic regression model for determinants of livelihood strategy: pastoral and off-farm

\begin{tabular}{|c|c|c|c|c|c|c|c|c|c|}
\hline \multicolumn{10}{|c|}{ Parameter estimates } \\
\hline \multicolumn{2}{|c|}{ Livelihood strategy } & \multirow[t]{2}{*}{ B } & \multirow[t]{2}{*}{ Std. error } & \multirow[t]{2}{*}{ Wald } & \multirow[t]{2}{*}{$d f$} & \multirow[t]{2}{*}{ Sig. } & \multirow[t]{2}{*}{$\operatorname{Exp}(B)$} & \multicolumn{2}{|c|}{$95 \%$ confidence interval for $\operatorname{Exp}(B)$} \\
\hline & & & & & & & & Lower bound & Upper bound \\
\hline \multirow[t]{10}{*}{ Pastoral } & Intercept & -2.333 & .473 & 24.284 & 1 & .000 & & & \\
\hline & Number of income sources ${ }^{a}$ & -.601 & .111 & 29.497 & 1 & .000 & .548 & .441 & .681 \\
\hline & Distance to water source ${ }^{b}$ & .059 & .026 & 4.986 & 1 & .026 & 1.061 & 1.007 & 1.117 \\
\hline & Education of household head ${ }^{\mathrm{b}}$ & -.079 & .026 & 9.138 & 1 & .003 & .924 & .878 & .973 \\
\hline & Age of household head ${ }^{b}$ & .017 & .006 & 7.031 & 1 & .008 & 1.017 & 1.004 & 1.029 \\
\hline & Total tropical livestock units ${ }^{a}$ & .049 & .009 & 29.978 & 1 & .000 & 1.051 & 1.032 & 1.069 \\
\hline & Durable index ${ }^{a}$ & .306 & .078 & 15.611 & 1 & .000 & 1.358 & 1.167 & 1.581 \\
\hline & Total tropical livestock units lost & .003 & .003 & .874 & 1 & .350 & 1.003 & .997 & 1.008 \\
\hline & {$[$ HHsex $=1]$} & .130 & .180 & .521 & 1 & .470 & 1.139 & .800 & 1.619 \\
\hline & {$[\mathrm{HH} \operatorname{sex}=2]$} & $0^{\mathrm{b}}$ & & & 0 & & & & \\
\hline
\end{tabular}

${ }^{\mathrm{a}}$ Significant at $99 \%$, ${ }^{\mathrm{b}}$ significant at $95 \%$

Pastoral households owned more livestock than agro-pastoral and off-farm households. This would be expected since ownership of livestock was the key indicator that was used to define a household as pastoral. At the same time, these households had their water sources spread over long distances as they occupied the most remote areas that could suitably be used for extensive grazing. If possession of livestock alone was to be the indicator of wealth, the pastoral households would be classified as the wealthiest. However, when other indicators of wealth such as the durable index were used, then agro-pastoral households emerged as the wealthiest. This observation exposes the weakness of using standard indicators to gauge pastoral well-being. Being relatively mobile, pastoral households are unlikely to accumulate fixed assets, although they could afford them if they wanted to. Lack of such assets among pastoral households may create a false impression about pastoral poverty.

\section{Factors influencing pursuance of pastoral, agro-pastoral and off-farm livelihoods}

A number of household characteristics were associated with whether a household was following a pastoral or off-farm livelihood strategy. These were the number of income sources, distance to water source, education level of household head, age of household head, number of livestock held (TLU) and durable index (Tables 5 and 6).

\section{Number of income sources}

The number of income sources was associated with pastoral or off-farm strategies. As the number of income sources increased by a unit, the chances of a household being engaged in off-farm livelihood strategy increased

Table 6 Logistic regression model for determinants of livelihood strategy: agro-pastoral and off-farm

\begin{tabular}{|c|c|c|c|c|c|c|c|c|c|}
\hline \multicolumn{2}{|c|}{ Livelihood strategy } & \multirow[t]{2}{*}{ B } & \multirow[t]{2}{*}{ Std. error } & \multirow[t]{2}{*}{ Wald } & \multirow[t]{2}{*}{$d f$} & \multirow[t]{2}{*}{ Sig. } & \multirow[t]{2}{*}{$\operatorname{Exp}(B)$} & \multicolumn{2}{|c|}{$95 \%$ confidence interval for $\operatorname{Exp}(B)$} \\
\hline & & & & & & & & Lower bound & Upper bound \\
\hline \multirow[t]{10}{*}{ Agro-pastoral } & Intercept & -25.089 & 3473.629 & .000 & 1 & .994 & & & \\
\hline & Number of income sources & .272 & .210 & 1.670 & 1 & .196 & 1.312 & .869 & 1.982 \\
\hline & Distance to water source & -.410 & .262 & 2.449 & 1 & .118 & .664 & .397 & 1.109 \\
\hline & Education of household head ${ }^{c}$ & -.185 & .051 & 13.369 & 1 & .000 & .831 & .752 & .918 \\
\hline & Age of household head ${ }^{a}$ & .021 & .013 & 2.776 & 1 & .096 & 1.022 & .996 & 1.047 \\
\hline & Total tropical livestock units & -.010 & .031 & .101 & 1 & .750 & .990 & .933 & 1.051 \\
\hline & Durable index ${ }^{b}$ & .396 & .128 & 9.482 & 1 & .002 & 1.485 & 1.155 & 1.911 \\
\hline & Total tropical livestock units lost ${ }^{a}$ & -.028 & .015 & 3.323 & 1 & .068 & .972 & .944 & 1.002 \\
\hline & {$[\mathrm{HH} \text { sex }=1]^{\mathrm{a}}$} & .586 & .354 & 2.747 & 1 & .097 & 1.797 & .899 & 3.592 \\
\hline & {$[\mathrm{HH}$ sex $=2]$} & $0^{b}$ & & & 0 & & & & \\
\hline
\end{tabular}

The reference category is off-farm Levels of sifnificance:'a' significant at $p<0.01$;'b' significant at $p=0.05$; 'c' significant at $p=0.1$ 
by $45 \%(p<0.001)$. The number of income sources however did not have significant influence on whether a household was pursuing an agro-pastoral or off-farm livelihood. An explanation for this could be that pursuance of a pastoral livelihood competes for labour with other livelihood options. When a household had low livestock per capita that could not sustain a pastoral livelihood, labour could be diverted to other livelihood options to ensure sustenance of the household.

\section{Education of the household head}

A unit increase in the number of schooling years increased the chances of a household undertaking an offfarm strategy by $8 \%(p=0.003)$ instead of pastoralism and reduced the likelihood of the household being agropastoral by $19 \%(p<0.001)$, meaning that increased literacy levels was associated with uptake of off-farm activities. Household heads engaged in pastoralism had low literacy levels compared to their counterparts pursuing agro-pastoralism or off-farm activities. Educational attainment has been shown to be a major determinant for engagement in remunerative non-farm activities (Barrett et al. 2001). Higher literacy levels among the heads therefore enabled pastoral households to diversify out of pastoralism. The number of different sources of income-generating activities practiced by a household was correlated with the number of formal schooling years of the household head. Household heads that had spent more years in formal learning institutions tended to be involved in more off-farm incomegenerating activities.

\section{Distance to water sources}

A unit increase in distance to water sources increased the likelihood of a household being pastoral than offfarm by $6 \%(p=0.026)$, an indication that pastoral households have to travel for longer distances in search of water compared to those households engaged in offfarm activities. Households located in the more interior remote areas were more likely to pursue a pastoral livelihood strategy as the opportunities of engaging in non-pastoral activities were more limited. Households engaged in off-farm activities were settled within trading centres that had better access to water.

\section{Tropical livestock units}

The number of livestock held by a household, expressed in terms of tropical livestock units (TLUs) varied significantly between pastoral and off-farm households and also between agro-pastoral and off-farm households. One unit increase in TLU increased the likelihood of a household being pastoral by $5 \%(p<0.001)$ as opposed to being off-farm. Pastoral households therefore tended to have more livestock than off-farm households.
Livestock holding was not significantly associated with whether an agro-pastoral household pursued off-farm activities.

\section{Age of the household head}

An increase of one unit in age of the household head increased the likelihood of a household being pastoral by $2 \%(p=0.008)$ as opposed to being off-farm. Off-farm activities were more pursed by younger people than older people. However, age was not a significant associated factor in uptake of off-farm activities as opposed to agro-pastoral livelihoods. Pursuance of pastoral livelihoods required that an individual accumulates a sizeable number of livestock and at the same time create good networks to ensure survival of the herd. Both pastoralism and agro-pastoralism required possession and access to assets, especially livestock and land. Limited access to these assets was a barrier to entrance to pastoral and agro-pastoral livelihoods by younger people. This implied that older people were more likely to take up livestock-based or crop-based opportunities whereas the young people were more likely to take up off-farm opportunities. Barrett et al. (2001) also observe that young people are more likely to diversify into off-farm livelihood activities compared to the elderly.

\section{Durable index}

Durable index is a measure of asset endowment and was a proxy indicator for household welfare. A household that had more assets had a higher durable index score. A comparison of this index score between pastoral and off-farm households revealed that a unit increase in the durable index score increased the likelihood of a household being pastoral by $36 \%(p<0.001)$ as opposed to being off-farm. Pastoral households therefore appeared to be wealthier than off-farm households when assessment was based on durable index score. At the same time, a unit increase in the durable index score increased the likelihood of a household being agro-pastoral by $49 \%(p=0.002)$ as opposed to being off-farm. Again, agro-pastoral households could be regarded as being better off than off-farm households.

\section{Poverty rates and livelihood strategies}

Classification of households by livelihood strategies showed that $68 \%$ and $67 \%$ of households pursuing offfarm and pastoral livelihoods, respectively, could be regarded as poor (very poor and poor) compared to only $45 \%$ among agro-pastoral households. The KruskalWallis test revealed that there was a significant difference in the current wealth status among households engaged in different livelihood strategies $(p<0.001)$. Further analysis by Mann-Whitney test for a pair-wise comparison of the three livelihood strategies showed 
that there was a significant difference in the wealth status between agro-pastoral and pastoral households $(p=0.012)$ and between agro-pastoral households and those pursuing off-farm livelihood strategies $(p<0.001)$. However, a comparison of pastoral households and offfarm households did not reveal any significant difference in their poverty levels $(p=0.228)$.

Our earlier comparison of the income of households across livelihood strategies depicted agro-pastoral households as the poorest as they received a paltry KShs 15,000 (USD 167) per year compared to off-farm and pastoral households that received KShs 75,000 (USD 833) and KShs 70,000 (USD 778), respectively. Assessment of how households had performed over a period of 20 years showed that agro-pastoral households were more resilient, as very few of such households dropped into poverty following environmental and economic shocks. Agro-pastoral households were able to survive drought events better than the pastoral and off-farm households as they would utilize their own produced food during the initial stages of a drought, thus reducing the negative impacts of drought. They were also able to use crop residues to supplement their animals during drought periods, thus saving some livestock that could otherwise been lost through the drought. However, promotion of agro-pastoralism as a livelihood option for pastoral communities is constrained, as it may only support about $20 \%$ and $5 \%$ of households in Turkana and Mandera, respectively, and this will have an insignificant impact as a poverty reduction strategy.

\section{Conclusion}

Livestock is the main source of livelihood among communities in pastoral areas of Turkana and Mandera, although only $24 \%$ of households have viable livestock herds to sustain pastoral livelihoods. Income earned from non-livestock activities contributes $61 \%$ and $77 \%$ of the total household income for Turkana and Mandera households, respectively. Use of cash income and accumulation of fixed assets as indicators of household welfare tend to erroneously depict pastoral households as poor, while use of livestock holding as the main indicator of wealth exaggerates pastoral welfare, depicting pastoral households as relatively rich compared to non-pastoral households.

The ability of households to engage in a livelihood strategy, whether pastoral or off-farm, depends on four socio-economic characteristics of the household: number of income sources, distance to water source, education level and age of household head. Due to demographic and gender constraints, males are more likely to engage in off-farm activities as compared to females.

\section{Recommendations}

Since livestock keeping under pastoral production system is still a major source of household incomes for households in northern Kenya, development strategies that complement livestock development will achieve greater success in ensuring sustenance of households. At the same time, households that must inevitably drop out of pastoralism need to be supported to take up other non-livestock-based alternatives, as these are also playing an increasingly important role in providing income to households.

Poverty assessments for pastoral areas need to use a variety of indicators to give objective results. Use of a few selected indicators may give misleading results as some aspects of household welfare may not be captured by some indicators.

Policy actions and interventions that improve education and access to water sources are likely to influence increased diversification among pastoral households. Development programmes that seek to promote diversification among pastoral households should address barriers that make it difficult for women to take up remunerative non-livestock-based opportunities.

\section{Competing interests}

The authors declare that they have no competing interests.

\section{Authors' contributions}

PWW collected the data, analysed the data, and structured the manuscript. WK-M, JN, LM and SM provided technical guidance on the structure of the manuscript. All authors read and approved the final manuscript.

\section{Authors' information}

PWW is a PhD student at the LARMAT Department, University of Nairobi, and Lecturer at Animal Health and Industry Training Institute (AHITI), Kabete, Kenya. WK-M, JN, OW and SM are lecturers at the College of Agriculture and Veterinary Sciences, University of Nairobi, Kenya.

\section{Acknowledgements}

The study was partly funded by the Carnegie Corporation of New York, through RUFORUM. Practical Action (EA) provided logistical support during field work.

\section{Author details \\ ${ }^{1}$ Land Resource Management and Agricultural Technology Department, University of Nairobi, Nairobi, Kenya. ${ }^{2}$ Animal Health and Industry Training Institute (AHITI), Kabete, Kenya. ${ }^{3}$ College of Agriculture and Veterinary Sciences, University of Nairobi, Nairobi, Kenya.}

Received: 8 August 2015 Accepted: 11 January 2016

Published online: 15 February 2016

\footnotetext{
References

Barrett, C.B., T. Reardon, and P. Webb. 2001. Non-farm income diversification and household livelihood strategies in rural Africa: Concepts, dynamics, and policy implications. Food Policy 26: 315-331.

Brown, D., E. Stephens, J. Ouma, F. Murithi, and C. Barrett. 2006. Livelihood strategies in the rural Kenyan highlands. African Journal of agricultural and Resource economics I(i): 21-36.

Carney, D. 1999. Sustainable rural livelihoods: What contribution can we make? London: DFID.

Catley, A., Lind, J., \& Scoones, I. (Eds.). 2013. Pastoralism and development in Africa: dynamic change at the margins. Routledge.
} 
Dhanaraj, S. 2015. Health shocks and the intergenerational transmission of inequality. United Nations University World Institute for Development Economics Research, University of Oxford.

Elasha, BO, Elhassan, NG, Ahmed, H, and Zakieldin, S. 2005. Sustainable livelihood approach for assessing community resilience to climate change: Case studies from Sudan. Assessments of Impacts and Adaptations to Climate Change (AIACC) Working Paper, 17.

Ellis, F. 2000. Rural livelihoods and diversity in developing countries. Oxford university press

Fratkin, E. 2012. Seeking alternative livelihoods in pastoral areas. In Risk and social change in an African rural economy: Livelihoods in pastoralist communities, ed. J. McPeak, P.D. Little, and I.R. Ross, 197-205. London and New York: Routledge.

Grootaert, C., and T. Bastelaer. 2002. Understanding and measuring social capital: A synthesis of findings and recommendations from the social capital initiative, The world Bank Washington DC and The IRIS Centre department of Economics. College Park Maryland USA: University of Maryland.

Kandagor, D.R. 2005. Rethinking pastoralism and African development. A case study of the Horn of Africa. Njoro, Kenya: Egerton University.

Krishna, A. 2010. Who became poor, who escaped poverty, and why? Developing and using a retrospective methodology in five countries. Journal of Policy Analysis and Management 29(2): 351-372.

Little, P, McPeak, J, Barrett, C, and Kristjanson, P. 2006. The multiple dimensions of poverty in pastoral areas of East Africa. In Pastoralism and Poverty Reduction in East Africa: A Policy Research Conference in Nairobi, Kenya

Bonfiglioli, A. M. \& Watson, C. J. 1992. Pastoralists at a Crossroads: Survival and development issues in African pastoralism. NOPA, UNICEF/UNSO Project for Nomadic Pastoralists in Africa.

Reardon, T., J. Gerdegue, and G. Escobar. 2001. Rural non-farm employment and incomes in Latin America: An overview and policy implications. World Development 29(3): 395-409.

Republic of Kenya. 2012. Sessional Paper No. 8 of 2012 on National policy for the sustainable development of Northern Kenya and other arid lands. Republic of Kenya, Nairobi: MDNKOAL.

Sandford, S. 2006. Too many people, too few livestock: The crisis affecting pastoralists in the Greater Horn of Africa. http://www.future-agricultures.org/ pdf\%20files/sandford thesis.pdf.

Scoones, I. (1998). Sustainable rural livelihoods: A framework for analysis. Brighton: IDS

Stifel, D. 2010. The rural non-farm economy, livelihood strategies and household welfare. African Journal of Agricultural and Resource economics. 4(1): 82-109.

Tache, B., and E. Sjaastad. 2010. Pastoralists conceptions of poverty: An analysis of traditional and conventional indicators from Borana, Ethiopia'. World Development 38(8): 1168-1178.

UNHCR. 2000. http://www.unhcr.org/pages/49e483a16.html, accessed on 29 September 2015

Von Braun, J, and Pandya-Lorch, R. 1991. Income sources of malnourished people in rural areas: Microlevel information and policy implications (No. 5). International Food Policy Research Institute (IFPRI). Washington, DC.

\section{Submit your manuscript to a SpringerOpen ${ }^{\circ}$ journal and benefit from:}

- Convenient online submission

- Rigorous peer review

- Immediate publication on acceptance

- Open access: articles freely available online

- High visibility within the field

- Retaining the copyright to your article

Submit your next manuscript at $\gg$ springeropen.com 